\title{
An Analysis of Phrasal Verbs in Subtitles of Sherlock - A Study in Pink
}

\author{
Sutrisno Sadji Evenddy ${ }^{1}$, Welliam Hamer' ${ }^{2}$ Dhafid Wahyu Utomo ${ }^{3}$, Hayun \\ Hamdalah $^{4}$
}

${ }^{1}$ English Education Study Program of Teacher Training and Education Faculty, Universitas Sultan Ageng Tirtayasa ${ }^{2}$ English Education Study Program of Teacher Training and Education Faculty, Universitas Sultan Ageng Tirtayasa ${ }^{3}$ English Education Study Program of Teacher Training and Education Faculty, Universitas Sultan Ageng Tirtayasa ${ }^{4}$ English Education Study Program of Teacher Training and Education Faculty, Universitas Sultan Ageng Tirtayasa

\section{ARTICLE INFO}

Keywords: Phrasal Verb

Transitive

Intransitive

Semantic Distinction

\begin{abstract}
The objective of this research is to describe the types and semantic distinctions of phrasal verb found in subtitles of TV-Series: Sherlock - A Study in Pink. The researchers used content analysis as research method and coding to collect data. The data sources of this research are phrasal verbs in subtitles of TV-Series: Sherlock A Study in Pink. This research used 3 steps in analyzing the data; data condensation, data display, drawing and verifying conclusions. Further, the researcher used investigator triangulation to verify and validate the data. As a result, there are 3 types of phrasal verbs found :intransitive, transitive-separable, and transitive-inseparable phrasal verbs. There are 30 data classified into intransitive phrasal verb, 23 data classified into transitive-separable phrasal verbs, and 5 data classified into transitive-inseparable phrasal verbs. The last, based on the analysis of semantic distinctions of phrasal verbs, it is found that there are 3 semantic distinctions of phrasal verbs, those are free idiomatic, semi idiomatic, and highly idiomatic phrasal verbs. There are 13 data classified into free idiomatic phrasal verbs, 22 data classified into semi idiomatic phrasal verbs, and 23 data classified into highly idiomatic phrasal verbs.
\end{abstract}

This is an open access article distributed under the terms of the Creative Commons Attribution 4.0 International License, which permits unrestricted use, distribution, and reproduction in any medium, provided the original work is properly cited. @ 2020 Sutrisno Sadji Evenddy, Welliam
mam Hamer, Dhafid Wahyu Utomo, Hayun Hamdalah

\footnotetext{
1 Corresponding author's address: English Education Study Program of Teacher Training and Education Faculty, Universitas Sultan Ageng Tirtayasa, Banten, Indonesia

e-mail: sutrisno.se@untirta.ac.id

2 Corresponding author's address: English Education Study Program of Teacher Training and Education Faculty, Universitas Sultan Ageng Tirtayasa, Banten, Indonesia

e-mail: welliamhamer@untirta.ac.id

3 Corresponding author's address: English Education Study Program of Teacher Training and Education Faculty, Universitas Sultan Ageng Tirtayasa, Banten, Indonesia

e-mail: dhafid.wu@untirta.ac.id

4 Corresponding author's address: English Education Study Program of Teacher Training and Education Faculty, Universitas Sultan Ageng Tirtayasa, Banten, Indonesia

e-mail: hayunevanhamdalah@gmail.com
} 


\section{INTRODUCTION}

Language is an important aspect for human beings in society. Human beings use language to communicate with others almost in every activity. According to Wibowo (2001: 3), language is a system of sound symbols that has meaning and articulation (produced by speech devices) that are arbitrary and conventional, used by human beings as a communication tool to produce feelings and thoughts. In brief, the essential function of language is for communicating.

However, communication needs understanding. It means that when communication occurs, the interlocutor must understand what the speaker says. This is based on what stated by Wood (2008:3) that communication is a systemic process in which individuals interact with and through symbols to create and interpret meanings. When the speakers transfer their ideas, thoughts, and intentions to the interlocutors through communication, it can only be possible if the interlocutors understand what the speakers want to be conveyed.

In case of English as foreign language, it is not easy for people as interlocutors to get some understanding in communication occur through two different languages. Interlocutors can understand accurately the language used if they understand every word the speakers say. This problem cannot simply be overcome by using dictionary. Dictionary only provides word for word translation, while sentence sometimes has some context and idiomatic meaning considered to be figured out. Moreover, there is a phrase in English known as phrasal verb, the multi-word verb. Phrasal verb is difficult to guess because it contains idiomatic meaning.

Phrasal verb is a type of compound verb made up of a verb (usually one of action or movement) and a prepositional adverb also known as an adverbial particle. Another definition of phrasal verb is "a phrase (such as take off or look down on) that combines a verb with a preposition or adverb or both and that functions as a verb whose meaning is different from the combined meanings of the individual words" (Merriam-Webster, 2017). In other words, the phrasal verb needs the object to complete the sentence. Here are the examples of these verbs:

(a) She always gets after me to give me a breakfast 'chase'.

(b) I am afraid if my slave will get away 'escaped'

It consists of verb get and particle (adverb) after. The word me as the pronoun is the object to complete and make sense the sentence. Meanwhile, intransitive phrasal verb which means it does not need the object. It is constructed by the verb get and particle (adverb) away without being followed by any object.

Phrasal verb can also be divided into separable and inseparable phrasal verb depending on the particle movement whether it can or it cannot be separated for example

(c) I have a lot of money to get around various laws 'avoid'.

(d) Relationship problem never gets me down 'make depressed'.

Sentence (c) is the type of sentence inseparable phrasal verb. The word get followed by particle around without being interjected by object between those two words. Sentence (d) is an example of the sentence of separable phrasal verb. The word me as a pronoun is an object that is put between verb gets and particle (preposition) down.

Some studies related to the analysis of phrasal verb have been conducted. Siregar (2013) in her analysis of novel, she simply classified the types of phrasal verb into transitive and intransitive phrasal verb using Greenbaum and Quirk's (1973) theory. However, the difficulty of learning phrasal verb is interpreting its meaning. In other words, the important aspect of analysing phrasal verb also involves classifying phrasal verb based on its meaning. There are some ways for researcher to come through it, such as the study that has been done by Juniardi, et al (2015) which used Newmark's (1988) translation theory. They classified phrasal verb into literal and semantic 
translation from the data taken using the students' test result of translation II subject at University of Sultan Ageng Tirtayasa.

Similar with the related studies, the researchers are interested in classifying phrasal verb into transitive and intransitive based on Quirk et al's (1985) theory. The researcher also classified phrasal verb into separable and inseparable using Coghill's (2003) theory. In classifying phrasal verb based on its meaning, the researcher also used Quirk, et al's (1985) theory which distinct phrasal verb into three categories; free idiomatic, semi idiomatic, and highly idiomatic.

In this research, the researchers is interested in analyzing phrasal verbs in subtitles of TV-Series: Sherlock - A Study in Pink. In this TV-Series, there are many verbs followed by particles such as look, put, take and pick verbs, but sometimes when those verbs are combined with particles, the researcher has no idea of what the meaning is. When the verb comes with particle, there will be either a separable phrasal verb or inseparable phrasal verb which causes shift- meaning from its literal meaning.

The sources of the data in this research are the subtitles of TV-Series: Sherlock - A Study in Pink which is downloaded from the internet. The series entitled Sherlock - A Study in Pink is an action mystery movie based on the character of the same name created by Sir Arthur Conan Doyle. The story of Sherlock Holmes is written by Lionel Wigram and Michael Robert Johnson. The screenplay is written by Michael Robert Johnson, Anthony Peckam, and Simon Kinberg.

\section{METHOD}

The researchers used content analysis. According to Bryman \& Bell (2011: 289), content analysis is an approach to the analysis of documents and texts (which may be printed or visual) that seek to quantify content in terms of predetermined categories and in a systematic and replicable manner. Furthermore, he (ibid) says that it is a very flexible method that can be applied to a variety of media. In other words, content analysis is a research method that can be used for studying documents and communication facts, which might be texts of various formats, pictures, audio or video. The researcher used the data which were collected from video file containing the subtitles of TV-Series: Sherlock - A Study in Pink.

The data of this research were phrasal verbs in subtitles of TV-Series: Sherlock - A Study in Pink; the subtitles were in English as the same as a transcription.. The transcripts of the series were taken from: http://subscene.com/subtitles/sherlock-first-season/english/348923

In this research, documentation technique was used for collecting data. According to Sarwono (2006: 225), documentation is the technique which help researcher in order to collect data or information in a way reviewing documents such as letters, announcements, report summary, warrant of certain policy and other documents. Bowen (2009: 27) also states that document analysis is a systematic procedure for reviewing or evaluating documents both printed and electronic (computer-based and Internet-transmitted) material. In this research, documentation was intended to obtain data directly from TV-Series: Sherlock - A Study in Pink and its English subtitles i.e. phrasal verbs. The length of each episode is about 90 minutes.

\section{Data Condensation}

Qualitative data need to be condensed and transformed in order to make them more readily accessible, understandable, and to draw out various themes and patterns. It directs attention to the need for focusing, simplifying, and transforming raw data into a more manageable form. As the project continues, further elements of data condensation will occur (written summaries, coding, development of grounded themes, identification of analytic themes, consideration of relevant theoretical explanations, etc.). This data condensation and transformation process occurs throughout the span of the research. 
In this step, the researcher collected the data after separating the data from other multi-word verbs such as prepositional verb and phrasal- prepositional verb by identifying the characteristics of phrasal verb. The researcher also used coding to condense the data; specifically protocol coding. According to Miles, et al (2014: 60), protocol coding is the appropriate coding for qualitative research. By labeling phrasal verb $(\mathrm{PhV})$ and its duration position (Mnt) the coding will be as following:

Table 1 describes the codification by labeling the phrasal verbsbased on their types and semantic distinctions.

Table 1 Table of Coding

\begin{tabular}{ccc}
\hline Phrasal Verb & Explanation & Coding \\
\hline \multirow{2}{*}{$\begin{array}{c}\text { Types of phrasal } \\
\text { verbs }\end{array}$} & Intransitive phrasal verb & IT \\
\cline { 2 - 3 } & Transitive phrasal verb & T \\
\cline { 2 - 3 } & Transitive, separable phrasal verb & S \\
\cline { 2 - 3 } & Transitive, inseparable phrasal verb & IS \\
\hline \multirow{2}{*}{$\begin{array}{c}\text { Semantic distinctions } \\
\text { of phrasal verbs }\end{array}$} & Free Idiomatic & FI \\
\cline { 2 - 3 } & Semi Idiomatic & SI \\
\cline { 2 - 3 } & Highly idiomatic & HI \\
\hline
\end{tabular}

Table 2 shows the coding process to classify the types of phrasal verbs. On the other hand, it was provided to answer formulation of the problem 1.

Table 2 Coding Sheet of Types of Phrasal Verbs

\begin{tabular}{ccccc}
\hline PhV & Mnt & IT & \multicolumn{3}{c}{ T } \\
\hline & & & T-S & T-IS \\
\hline Get around & $08: 00$ & & & (- \\
\hline Get up & $12: 30$ & ๑ & & \\
\hline$\ldots \ldots \ldots$ & & & & \\
\hline
\end{tabular}

The coding process to classify the semantic distinctions can be seen at table 3.3 below. Further, it was used to answer formulation of problem 2 (see table 3).

Table 3. Coding sheet of Semantic Distinctions of Phrasal Verbs

\begin{tabular}{|c|c|c|c|c|c|}
\hline PhV & Mnt & FR-Id & SM-Id & HL-Id & Meaning \\
\hline Get around & $08: 00$ & & & $\odot$ & 'avoid problem' \\
\hline Get up & $12: 30$ & & $\odot$ & & 'arise' \\
\hline$\ldots \ldots .$. & & & & & \\
\hline
\end{tabular}

For deciding the meanings of semantic distinctions of phrasal verbs, the researchers used phrasal verb dictionary and some trusted websites of phrasal verb dictionary such as: Cambridge phrasal verb dictionary, http://www.oxfordlearnersdictionaries.com, http://www.merriam-webster.com, http://www.collinsdictionary.com, http://www.macmillandictionary.com

\section{Data Display}

The notion of data display was intended to convey the idea that data were presented as an organized, compressed assembly of information that permits conclusions to be analytically drawn. Displays might involves tables of data; tally sheets of themes; summaries or proportions of various statements, phrases, or terms; and similarly reduced and transformed groupings of data. These displays assisted the researcher in understanding and observing certain patterns in the data or determining what additional analysis or actions must be taken. As with the activity of data condensation, the development of displays was not really a separate step but rather a component of the analysis process. In displaying the data, the data were sorted, listed, and categorized of each types and semantic distinction using tables. 


\section{Drawing and Verifying Conclusions}

The last analysis activity was drawing and verifying conclusion. After the analyzing process and displaying them into tables, it helped the researcher to understand and conclude the findings from the research. Nevertheless, in this step, the researcher should concentrate to verify the data whether there still be found mistake in data because this was the important part in research. Next, the researcher concluded the findings into more understandable sentences. Verifying and Conclusion Drawing is where the data has been analyzed and validated through the theories that used in this research.

\section{Research Instruments}

Commonly, qualitative research involves the researcher him/herself to be the main instrument. According to Moleong (2008) in Pongtiku, et al (2016: 237), in qualitative research, a researcher is a planner, a data collector, an analyst, a data interpreter and a reporter of research result. Therefore, as this research is qualitative research, the primary instrument of the research was the researcher himself, who had the role of planning, collecting, analyzing and reporting the research findings. The researcher also used the coding sheets and inter-rater sheets and designed based on Paltridge \& Starfield's theory (2007) which simply used checklist to classify the data.

\section{Data Trustworthiness}

A technique which is commonly employed to enhance trustworthiness in qualitative research is triangulation. Triangulation requires using several methods to address the same question in order to gain trustworthiness of the data (Vanderstoep \& Johnson, 2009: 179). According to Pongtiku, et al (2016: 101), there are four types of triangulation, i.e. source triangulation, investigator triangulation, methodological triangulation, theory triangulation.

In order to gain credibility and reliability of the data, this research employed an investigator triangulation. Investigator triangulation is the use of more than one investigator (examiner or rater in a study). The ability to confirm findings across raters without prior discussion or collaboration between them can significantly enhance the credibility of the findings (Hales, 2010: 15). Using investigator triangulation, the data were triangulated by raters; the lecturers of translation subject from University of Sultan Ageng Tirtayasa.

\section{DISCUSSION}

Phrasal verbs are divided into intransitive and transitive. Meanwhile, phrasal verbs can be inseparable and separable. The important thing to be noticed is that transitive phrasal verbs can be separable or inseparable, while all intrasitive phrasal verbs are inseparable. It is obvious because intransitive phrasal verbs do not have object to separate them. Therefore, inseparable phrasal verbs that are used as data findings are only from transitive phrasal verbs.

\section{Intransitive Phrasal Verbs}

Intransitive phrasal verb is phrasal verb which takes no object and has two patterns; verb + adverb $(\mathrm{V}+\mathrm{ADV})$ and verb + preposition $(\mathrm{V}+\mathrm{Prep})$. Therefore, intransitive phrasal verb is unnecessary classified to separable or inseparable phrasal verb as it is mentioned before. The researcher has found 30 data of intrasitive phrasal verbs. Here is the example.

\begin{tabular}{cccc}
\hline Data No & Phrasal Verb & Minute & \multicolumn{1}{c}{ Source Text } \\
\hline 1 & Help out & 13:14 & - I was able to help out. \\
& &
\end{tabular}

The type of phrasal verb above is intransitive phrasal verb because the phrasal verb takes no object by using pattern V + ADV. It means that the phrasal verb is constructed only by verb "help" and adverb "out". 


\section{Transitive Phrasal Verb}

Transitive phrasal verb takes object. The object can be positioned after the adverb or preposition and it can also be positioned before the adverb or preposition. It also has four patterns, such as $(\mathrm{V}+\mathrm{N}+\mathrm{ADV}),(\mathrm{V}+\mathrm{ADV}+\mathrm{N}),(\mathrm{V}+\mathrm{Prep}+\mathrm{N})$, and $\mathrm{V}+\mathrm{N}+\mathrm{Prep})$. The researcher has found 23 data of transitive separable phrasal verbs. Here is the example.

\begin{tabular}{|c|c|c|c|}
\hline Data No & Phrasal Verb & Minute & Source Text \\
\hline & & & hton thino on hit \\
\hline
\end{tabular}

The type of phrasal verb above is transitive phrasal verb because the phrasal verb takes object. The phrasal verb has an object as noun $(\mathrm{N})$ "things", and it comes before the adverb (ADV) "up". It means the phrasal verb is separable with pattern $\mathrm{V}+\mathrm{N}+\mathrm{ADV}$.

\section{Transitive, Inseparable Phrasal Verbs}

Transitive phrasal verb takes object where the object is only positioned after the adverb or preposition. It only has two patterns, $(\mathrm{V}+\mathrm{ADV}+\mathrm{N})$ and $(\mathrm{V}+\mathrm{Prep}+\mathrm{N})$. The researcher has found 5 data of transitive inseparable phrasal verbs. Here the example:

\begin{tabular}{cccc}
\hline Data No. & Phrasal Verb & Minute & Source Text \\
\hline 24 & Get into & $34: 18$ & Get into the car, Dr Watson. \\
\hline
\end{tabular}

The type of phrasal verb above is transitive phrasal verb because the phrasal verb takes object. The phrasal verb has an object $(\mathrm{N})$ "the car", and it comes after the preposition (Prep) "into". It cannot be possible to place the object in the middle of the verb and particle even though using pronoun "it". It means the phrasal verb is inseparable with pattern V + Prep + N.

\section{Semantic Distinctions of Phrasal Verbs}

Phrasal verbs have interesting semantic differences. Quirk, et al (1985: 1162) provides three types of semantic distinctions of phrasal verbs, such as free idiomatic phrasal verb, semi idiomatic phrasal verb, and highly idiomatic phrasal verb. The types of semantic distinctions that found in subtitles of TV-Series: Sherlock - A Study in Pink are drawn in the following below:

\section{Free Idiomatic Phrasal Verbs}

In this category, the verb retains its basic concrete meaning while the short adverb or preposition maintains a literal meaning. Such combinations are the easiest for language learners to understand and learn because the individual meanings of the components are apparent constancy in possible substitution. The researcher has found 13 data of free idiomatic phrasal verbs. Here is the example.

\begin{tabular}{cccc}
\hline Data No. & Phrasal Verb & Minute & Source Text \\
\hline 2 & Come in & $13: 25$ & $\begin{array}{c}\text { Hello. Come in. } \\
\text { Thank you. }\end{array}$ \\
\hline
\end{tabular}

The phrasal verb "come in" in the sentence above is classified into free idiomatic phrasal verb. It is because the particle retains its adverbial meaning and do not change the meaning of the verb. The verb "come" means to move toward something and the particle "in" means "to the inside of (a room, building, etc.)". The phrasal verb "come in" means to enter the room, building or another place. The sentence above is about Mrs. Hudson wanted Sherlock and John to enter her house. Thus, the sentence means come to the inside of the house.

\section{Semi Idiomatic Constructions}

In this category, the constructions are variable but in a more limited way. The verb word keeps its meaning, whereas the meaning of the particle is less easy to isolate. Even though the exact meaning of these phrasal verbs might not be clear, an approximate meaning might 
be understood by a language learner. The researcher has found 22 data of semi idiomatic phrasal verbs. Here the example.

\begin{tabular}{cccc}
\hline Data No. & Phrasal Verb & Minute & Source Text \\
\hline 3 & Move in & $14: 03$ & So I went straight ahead and moved in. \\
\hline
\end{tabular}

The phrasal verb "move in" in this sentence is classified into semi idiomatic phrasal verb. It is because the verb "move" retains its concrete meaning, but the particle "in" adds a nuance that would not be discernible from its basic meaning. The phrasal verb "move in" means "to start living in a different house or flat". Thus, the sentence above is about Sherlock tells John that he has moved to his new flat and started living there because the place is very nice. Thus, the sentence means I went straight ahead and moved to start living.

\section{Highly Idiomatic Phrasal Verbs}

In this category, the combination words of phrasal verbs are fully idiomatic. No part of the meaning of the combination is predictable from the meanings of the verb and the short adverb or the preposition. These are thoroughly idiomatic in that there is no possibility of contrastive substitution. The researcher has found 23 data of highly idiomatic phrasal verbs. Here is the example.

\begin{tabular}{cccc}
\hline Data No & Phrasal Verb & Minute & Source Text \\
\hline 6 & Piss off & $21: 00$ & $\begin{array}{c}\text { That's not what people normally say. } \\
\text { What do people normally say? Piss off!" }\end{array}$ \\
\hline
\end{tabular}

The phrasal verb "piss off" in the sentence above is classified into highly idiomatic phrasal verb. It means that the phrasal verb creates different meaning from its individual words. The meaning of each part of the combination is not predictable and there is no possibility of substitution for the verb and the particle. However, the verb "piss" and particle "off" in phrasal verb constructions create new meaning "go away" or to tell someone to go away or that you are annoyed with them. Thus, the sentence above means Sherlock tells John that no one wants Sherlock to be near, and they are always say to Sherlock to go away.

The research's purpose is to analyze the phrasal verbs in subtitles of TV- Series: Sherlock - A Study in Pink. It is found from the data analysis that there are 58 phrasal verbs in subtitles of TV-Series: Sherlock - A Study in Pink. There are two objectives of the analysis; the types of the phrasal verbs and semantic distinctions of the phrasal verbs. The findings are drawn in the following table:

Table of types of phrasal verbs

\begin{tabular}{cccc}
\hline \multirow{2}{*}{ No } & \multicolumn{2}{c}{ Types of phrasal verbs } \\
\cline { 2 - 3 } & Transitive phrasal verb & Intransitive \\
& Separable & inseparable & phrasal verb \\
\hline 1 & Straighten up & Get into & Help out \\
\hline 2 & Give away & Dispose of & Come in \\
\hline 3 & Bring in & Break into & Move in \\
\hline 4 & Work out & Set up & Piss off \\
\hline 5 & Put on & Look for & Get on \\
\hline 6 & Keep out & Split up \\
\hline 7 & Make up & Come around \\
\hline 8 & Work off & Stay over \\
\hline 9 & Get back & Shut up \\
\hline 10 & Put back & Pass out \\
\hline 11 & Stand down & Take off \\
\hline 12 & Put off & Get off \\
\hline 13 & Narrow down & Show up \\
\hline
\end{tabular}




\begin{tabular}{ccc}
\hline 14 & Bring back & Sit down \\
\hline 15 & Take down & Stop off \\
\hline 16 & Let down & Hang on \\
\hline 17 & Walk in & Black out \\
\hline 18 & Take away & Get out \\
\hline 19 & Get together & Come on \\
\hline 20 & Point out & Go away \\
\hline 21 & Pull in & Talk out \\
\hline 22 & Keep up & Pop outside \\
\hline 23 & Keep down & Drive off \\
\hline 24 & & Ring out \\
\hline 25 & & Put up \\
\hline 26 & & Branch out \\
\hline 27 & & Go on \\
\hline 28 & & Cut out \\
\hline 29 & & Clear off \\
\hline 30 & 23 & Turn up \\
\hline Total & & 30 \\
\hline
\end{tabular}

It shows there are two main types of phrasal verbs; transitive phrasal verb and intransitive phrasal verb. Transitive phrasal verbs can be separable or inseparable. Besides, intransitive phrasal verb is always in inseparable form because it does not take object. From 58 phrasal verbs of the total data, there are 23 data of transitive separable phrasal verb, 5 data of transitive inseparable phrasal verb, and 30 data of intransitive phrasal verbs

Table of semantic distinctions

\begin{tabular}{|c|c|c|c|}
\hline \multirow[t]{2}{*}{ No. } & \multicolumn{3}{|c|}{ Semantic distinction } \\
\hline & Free idiomatic & Semi Idiomatic & Highly idiomatic \\
\hline 1 & Come in & Help out & Piss off \\
\hline 2 & Bring in & Move in & Get on \\
\hline 3 & Put on & Straighten up & Work out \\
\hline 4 & Keep out & Give away & Shut up \\
\hline 5 & Get into & Split up & Work off \\
\hline 6 & Sit down & Come around & Take off \\
\hline 7 & Get out & Stay over & Get off \\
\hline 8 & Get back & Pass out & Hang on \\
\hline 9 & Break into & Make up & Black out \\
\hline 10 & Put back & Show up & Dispose of \\
\hline 11 & Narrow down & Stop off & Come on \\
\hline 12 & Bring back & Go away & Stand down \\
\hline 13 & Walk in & Talk out & Set up \\
\hline 14 & & Branch out & Look for \\
\hline 15 & & Drive off & Put off \\
\hline 16 & & Ring out & Pop outside \\
\hline 17 & & Let down & Take down \\
\hline 18 & & Take away & Put up \\
\hline 19 & & Point out & Go on \\
\hline 20 & & Cut out & Get together \\
\hline 21 & & Keep up & Clear off \\
\hline 22 & & Keep down & Pull in \\
\hline
\end{tabular}




\begin{tabular}{|c|c|c|c|}
\hline 23 & & & Turn up \\
\hline \multicolumn{4}{|l|}{24} \\
\hline \multirow[t]{2}{*}{ Total } & 13 & 22 & 23 \\
\hline & & 58 & \\
\hline
\end{tabular}

It shows that there are three semantic distinctions of phrasal verbs; free idiomatic, semi idiomatic, amd highly idiomatic. From 58 data obtained, there are 13 data of free idiomatic phrasal verb, 22 data of semi idiomatic phrasal verb, and 23 data of highly idiomatic phrasal verb. The important thing should be noticed is that the data of phrasal verbs above are not persistent. It means that free idiomatic phrasal verb can be highly idiomatic or vice versa depending on the context. For example, the phrasal verb get on above is classified into highly idiomatic phrasal verb whereas it can also be free idiomatic phrasal verb in some context.

\section{CONCLUSION}

Based on the analysis of types of phrasal verbs in subtitles of TV-Series: Sherlock - A Study in Pink, it is concluded that there are three types of phrasal verbs, those are intransitive, transitive separable, and transitive inseparable. These are based on two main types of phrasal verbs; transitive phrasal verb and intransitive phrasal verb. Transitive phrasal verb has branch types of phrasal verbs; transitive separable phrasal verb and transitive inseparable phrasal verb. Intransitive phrasal verb takes no object and it has two patterns; verb + preposition (Verb + Prep) and verb + adverb $(\mathrm{V}+\mathrm{ADV}$ ) (see page 31). Besides, transitive phrasal verb takes object in its construction and it has four patterns; verb + preposition + noun $(V+$ Prep $+N)$, verb + noun + preposition $(\mathrm{V}+\mathrm{N}+$ Prep $)$, verb + adverb + noun $(\mathrm{V}+\mathrm{ADV}+\mathrm{N})$, and verb + noun + adverb $(\mathrm{V}+\mathrm{N}$ $+\mathrm{ADV})$ (see page 40). Separable phrasal verb is phrasal verb that the verb can be separated from its particle, while inseparable phrasal verb is phrasal verb that the verb cannot be separated from its particle.

Free idiomatic phrasal verb retains its meaning of verb and the particle maintains a literal meaning. Then, semi idiomatic phrasal verb also retains its meaning of verb, but the particle adds a nuance that would Based on the analysis of semantic distinctions of phrasal verbs, it is concluded that there are three semantic distinctions of phrasal verb found in subtitles of TV-Series: Sherlock - A Study in Pink. They are free idiomatic phrasal verb, semi idiomatic phrasal verb, and highly idiomatic phrasal verb. not be discernible from its basic meaning. The last, highly idiomatic phrasal verb has fully idiomatic combination. No part of the meaning of the combination is predictable from the meanings of the verb and the short adverb or the preposition.

\section{REFERENCES}

Bowen, G. A. (2009). Document Analysis as a Qualitative Research Method. Qualitative Research Journal , 27.

Bryman, A., \& Bell, E. (2011). Business Research Methods 3rd Edition. Oxford: Oxford University Press.

Coghill, J. (2003). English Grammar. Newyork: Wiley.

Hales, D. (2010). An Introduction to Triangulation. Geneva: UNAIDS.

Merriam-Webster. (2017). Retrieved February Thursday, 2019, from Merriam- Webster: https://www.merriam-webster.com/dictionary/phrasal\%20verb

Miles, M. B., Huberman, A. M., \& Saldana, J. (2014). Qualitative Data Analysis A Methods Sourcebook. Los Amgeles: SAGE Publications, Inc.

Moleong, L. J. (2005). Metodologi Penelitian Kualitatif. Bandung: PT Remaja Rosdakarya.

Newmark, P. (1988). A Textbook of Translation. New York: Prentice Hall. 
Paltridge, B., \& Starfield, S. (2007). Thesis and Dissertation Writing in a Second Language. New York: Routledge.

Pongtiku, A., Kayame, R., Rerey, V. H., Suprapto, T., \& Resubun, Y. (2016). Metode Penelitian Kualitatif Saja. Jayapura: Nulisbuku.com.

Quirk, R., Greenbaum, S., Leech, G., \& Svartvik, J. (1985). A Comprehensive Grammar of The English Language. New York: Longman.

Sarwono, J. (2006). Metode Penelitian Kuantitatif \& Kualitatif. Yogyakarta: Graha Ilmu. Siregar, A. S. (2013). An Analysis of Phrasal Verbs in Khaled Hosseini's Novel: A Thousand Splendid Suns. Medan: University of Sumatera Utara.

Vanderstoep, S. W., \& Johnson, D. D. (2009). Research Method of Everyday Life. San Fransisco: JosseyBass.

Wibowo, W. (2001). Manajemen Bahasa. Jakarta: Gramedia.

Wood, J. T. (2008). Communication in Our Lives 5th Edition. Boston: Wadsworth. 